University of Wollongong

Research Online

Faculty of Engineering and Information

Faculty of Engineering and Information

Sciences - Papers: Part A

Sciences

$1-1-2014$

\title{
Microstructural evolution and mechanical property of AA5050 alloy deformed by accumulative roll bonding
}

Kuiyu Cheng

University of Wollongong, kc938@uowmail.edu.au

Cheng Lu

University of Wollongong, chenglu@uow.edu.au

A Kiet Tieu

University of Wollongong, ktieu@uow.edu.au

Hongtao Zhu

University of Wollongong, hongtao@uow.edu.au

Follow this and additional works at: https://ro.uow.edu.au/eispapers

Part of the Engineering Commons, and the Science and Technology Studies Commons

Research Online is the open access institutional repository for the University of Wollongong. For further information contact the UOW Library: research-pubs@uow.edu.au 


\title{
Microstructural evolution and mechanical property of AA5050 alloy deformed by accumulative roll bonding
}

\author{
Abstract \\ In this study, ultrafine-grained AA5050 sheets were fabricated by the accumulative roll bonding (ARB) \\ process. Transmission electron microscope observations showed that at the early stage of ARB, the grain \\ size was reduced in the normal direction and became elongated along the rolling direction. The elongated \\ grains were cut out by dense dislocations, which then tangled and condensed, resulting in the formation \\ of dislocation cells. As the deformation proceeded, the dislocation cells evolved to sub-grain boundaries \\ and then grain boundaries. The ultrafinegrained microstructure was obtained via four ARB cycles. The \\ tensile tests at $473 \mathrm{~K}$ and $523 \mathrm{~K}$ ( 200 degrees $\mathrm{C}$ and 250 degrees $\mathrm{C}$ ) showed large elongations for strain \\ rates of $1 \times 103 \mathrm{~s}-1$ and $1 \times 104 \mathrm{~s}-1$
}

\section{Keywords}

accumulative, roll, bonding, aa5050, evolution, alloy, microstructural, property, mechanical, deformed

Disciplines

Engineering | Science and Technology Studies

\section{Publication Details}

Cheng, K., Lu, C., Tieu, A. K. \& Zhu, H. (2014). Microstructural evolution and mechanical property of AA5050 alloy deformed by accumulative roll bonding. Metallurgical and Materials Transactions B: Process Metallurgy and Materials Processing Science, 45B (2), 399-403. 


\title{
Microstructural Evolution and Mechanical Property of AA5050 Alloy Deformed by Accumulative Roll Bonding
}

\author{
KUIYU CHENG, CHENG LU, KIET TIEU, and HONGTAO ZHU \\ In this study, ultrafine-grained AA5050 sheets were fabricated by the accumulative roll bonding \\ (ARB) process. Transmission electron microscope observations showed that at the early stage of \\ $\mathrm{ARB}$, the grain size was reduced in the normal direction and became elongated along the rolling \\ direction. The elongated grains were cut out by dense dislocations, which then tangled and \\ condensed, resulting in the formation of dislocation cells. As the deformation proceeded, the \\ dislocation cells evolved to sub-grain boundaries and then grain boundaries. The ultrafine- \\ grained microstructure was obtained via four ARB cycles. The tensile tests at $473 \mathrm{~K}$ and $523 \mathrm{~K}$ \\ $\left(200{ }^{\circ} \mathrm{C}\right.$ and $\left.250{ }^{\circ} \mathrm{C}\right)$ showed large elongations for strain rates of $1 \times 10^{3} \mathrm{~s}^{-1}$ and $1 \times 10^{4} \mathrm{~s}^{-1}$.
}

DOI: $10.1007 / \mathrm{s} 11663-013-9842-8$

(C) The Minerals, Metals \& Materials Society and ASM International 2013

\section{INTRODUCTION}

THE physical and mechanical properties of polycrystalline metals, such as conductivity, ductility, and strength, can be improved by refining the grains. ${ }^{[1]}$ Severe plastic deformation methods, including equal channel angular pressing (ECAP) ${ }^{[2-12]}$ accumulative roll bonding (ARB), ${ }^{[13-15]}$ and multidirectional forging (MDF), ${ }^{[16-23]}$ have been widely used to achieve ultrafinegrained structure in numerous metal alloys. The investigation on the grain refinement mechanism during SPD has recently attracted significant research interest. The grain refinement for metals with medium or high stacking fault energy (SFE) is generally related to dislocation activities, including formation of dislocation cells (DCs), transformation of DC walls into subboundaries with small misorientation angles, and evolution of sub-boundaries into highly misoriented grain boundaries. ${ }^{[24-28]}$ The minimum size of refined grains via this process is about $100 \mathrm{~nm}$. It has also been found that the strain rate plays an important role in grain refinement. When a high strain rate was applied to $\mathrm{Cu}$, the high-density and nanometer-thick deformation twins were formed. The combined activities of twinning and dislocations resulted in a minimum grain size of about $10 \mathrm{~nm} \cdot{ }^{[24,25]}$ In a particular case where the fcc austenite has a low SFE $\left(17 \mathrm{~mJ} / \mathrm{m}^{2}\right)$, the stress-induced martensitic transformation played a certain role in the formation of nanocrystallites. ${ }^{[26]}$

In the present study, the evolving microstructure of AA5050 Aluminum alloy sheets during accumulative roll bonding has been investigated. It has been found that the grain structure was significantly refined via four cycles of ARB processing and the refining mechanism

KUIYU CHENG, Student, CHENG LU and HONGTAO ZHU, Senior Lecturers, and KIET TIEU, Professor, are with the School of Mechanical, Materials and Mechatronics Engineering, University of Wollongong, Northfields Avenue, Wollongong, NSW 2522, Australia. Contact e-mail: chenglu@uow.edu.au

Manuscript submitted January 9, 2013.

Article published online April 16, 2013. was dominated by the formation of dislocation walls and dislocation tangles which gradually formed the subgrain boundaries and high-angle grain boundaries that divided the lamellar grains. Due to the ultrafine-grained microstructure, the ARB-processed AA5050 presented large tensile plastic deformation at $473 \mathrm{~K}$ and $523 \mathrm{~K}$ $\left(200{ }^{\circ} \mathrm{C}\right.$ and $\left.250^{\circ} \mathrm{C}\right)$, with strain rates of $1 \times 10^{3} \mathrm{~s}^{-1}$ and $1 \times 10^{4} \mathrm{~s}^{-1}$.

\section{EXPERIMENTAL}

The Aluminum alloy AA5050 sheets with an initial thickness of $1.36 \mathrm{~mm}$ were used in this study to investigate the microstructure evolution during the ARB process and the subsequent superplasticity. Table I lists the chemical composition of AA50500. As-received AA5050 sheets were cut parallel to the original rolling direction (RD) in 50 -mm-wide by 20 -mm-long pieces. Two pieces of specimens were then stacked together, welded at one end, and roll bonded after surface treatments (degreasing and wire brushing). At each rolling pass, the thickness was reduced by about $50 \%$. The above procedure proceeded for 4 cycles. The entire roll bonding process was carried out without any lubrication in order to increase the shear deformation. The samples were preheated at $523 \mathrm{~K}$ $\left(250{ }^{\circ} \mathrm{C}\right)$ for 3 minutes before each rolling pass. The roll bonding process was carried out in a two-high experimental rolling mill. The rolls were $125 \mathrm{~mm}$ diameter by $280 \mathrm{~mm}$ length (length of the barrel) and they were manufactured from Böhler W302 tool steel; their peripheral speed was $196 \mathrm{~mm} / \mathrm{s}$. The roughness of the rolls was $\mathrm{Ra}=0.28 \mu \mathrm{m}$ along the circumferential direction and $\mathrm{Ra}=0.34 \mu \mathrm{m}$ along the axial direction. The roll gap could be set by a mechanical screw down system and two hydraulic capsules. The detailed process parameters are shown in Table II.

Prior to each rolling pass, the 10 - to $30-\mathrm{nm} \mathrm{Al}_{2} \mathrm{O}_{3}$ particles were spread uniformly with a scraper knife at the interfaces between the two specimens with the distribution 
amount of about $0.25 \mathrm{mg} / \mathrm{mm}^{2}$. It has been proved in a previous study that the interfacial bonding can be significantly enhanced with the assistance of the nanosized particles embedded at the contact interfaces. ${ }^{[27]}$

The previous studies showed that the grain size can be significantly reduced by the first one or two ARB cycles. $^{[13-15]}$ With further processing, the grain size decreases slowly. ${ }^{[28,29]}$ In Kim et al.'s ${ }^{[28]}$ study, it has been found that the grain boundary spacing along the specimen thickness direction reduced down to $300 \mathrm{~nm}$ after three ARB cycles; however, the grain size remained nearly unchanged after the fourth cycle. More ARB cycles can result in obvious microstructure recovery and the precipitation of second phases in Al alloys. ${ }^{[28,30]}$ Therefore, only four cycles of ARB were carried out in the present study.

After each ARB process, thin foils were cut out from both the center and the edge (near surface) positions of the selected ARB-deformed samples using the focus ion beam (FIB) method for transmission electron microscopy (TEM) observation. TEM observations were carried out on a JOEL JEM 2011 microscope operating at $200 \mathrm{kV}$. An area of about $2.6 \mu \mathrm{m}$ in diameter was used to obtain the grain orientation relationships by selected area diffraction (SAD) patterns. Samples for the tensile test were machined from the four-cycle ARB-processed samples along the RD with a gage dimension of $6 \mathrm{~mm} \times 2 \mathrm{~mm}$ (length $\times$ width) as shown in Figure 1. Tensile tests were carried out on a servocontrolled Instron tensile machine at $473 \mathrm{~K}$ and $523 \mathrm{~K} \quad\left(200{ }^{\circ} \mathrm{C}\right.$ and $\left.250{ }^{\circ} \mathrm{C}\right)$ with strain rates of $1 \times 10^{3} \mathrm{~s}^{-1}$ and $1 \times 10^{4} \mathrm{~s}^{-1}$ to failure.

\section{RESULTS AND DISCUSSION}

Figure 2 shows the microstructure of the starting material AA5050 used in the present study. The RD and

Table I. Chemical Composition of the AA5050 Al Alloy Used in this Study

\begin{tabular}{ll}
\hline Element & Wt Pct \\
\hline $\mathrm{Si}$ & 0.40 \\
$\mathrm{Fe}$ & 0.70 \\
$\mathrm{Cu}$ & 0.20 \\
$\mathrm{Mn}$ & 0.10 \\
$\mathrm{Mg}$ & 1.50 \\
$\mathrm{Cr}$ & 0.10 \\
$\mathrm{Zn}$ & 0.25 \\
$\mathrm{Al}$ & balance \\
\hline
\end{tabular}

normal direction (ND) are marked by arrows in the figure. The starting material was hot rolled without recrystallization heat treatment. It contained a certain number of dislocations distributed relatively uniformly throughout the whole material, although some grains were clearly tangled at the grain boundaries. In Al and Al alloys, which have relatively high stacking fault energies among the fcc metals, the formation of dislocation walls and dislocation tangles are mainly responsible for grain refinement because twinning is difficult. Therefore, the preexistent dislocations in the starting materials would play a significant role in the subsequent grain refining process. The selected area diffraction pattern did not show a single net pattern, but it showed a scattered one, which implied there were certain highangle grain boundaries. The grains were about 1 to $2 \mu \mathrm{m}$ in size. The average boundary spacing parallel to the rolling direction $\left(d_{l}\right)$ and perpendicular to the rolling plan $\left(d_{n}\right)$ was measured by the intersection method and is listed in Table III with the aspect ratio $\left(d_{l} / d_{n}\right)$.

The inset in Figure 3 shows the $\langle 110\rangle$ zone axis diffraction patterns. It can be seen that there were some precipitations of $\mathrm{Al}_{3} \mathrm{Mg}_{2}$ in the samples. The agglomerate dislocations were concentrated on the phase interface due to the coherent stress. However, because the $\mathrm{Al}_{3} \mathrm{Mg}_{2}$ phase was very low in content, its effect on subsequent grain refining process and mechanical properties is insignificant.

After two cycles of ARB, the grains were obviously elongated in the rolling direction and the grain boundary spacing in the ND was severely reduced in the center of the samples (Figure 4). The relatively large deformation has also caused a considerable number of dislocations to form inside the grains and on their boundaries. The selected area diffraction pattern showed a ring pattern, which indicated that an ultrafine-grained structure with high-angle grain boundaries began to be generated at this stage. Most of the high-angle grain boundaries were parallel to the rolling direction, while the elongated grains were clearly separated by them. A few short interconnecting boundaries lying between the lamellar boundaries formed the so-called elongated cell block structure similar to that observed in commercial purity $\mathrm{Al}$ and AA8011 Al alloys. ${ }^{[31,32]}$ However, near the surface of the sample (Figure 5), the grain structure had not been severely elongated and the short grain boundaries which were almost perpendicular to the rolling direction increased markedly because the elongated grains were broken by the large shear deformation near the surface in the form of dislocation cutting and grain rotation. Figure 5(b)) clearly shows an elongated grain separated by low, parallel grain boundaries

Table II. Processing Parameters for the ARB Experiments

\begin{tabular}{lcccccc}
\hline Pass No. & $\begin{array}{c}\text { Entry Thickness } \\
(\mathrm{mm})\end{array}$ & $\begin{array}{c}\text { Exit Thickness } \\
(\mathrm{mm})\end{array}$ & $\begin{array}{c}\text { Rolling Speed } \\
(\mathrm{mm} / \mathrm{s})\end{array}$ & Reduction & $\begin{array}{c}\text { True } \\
\text { Strain (\%) }\end{array}$ & $\begin{array}{c}\text { Accumulative } \\
\text { True Strain }\end{array}$ \\
$\begin{array}{l}\text { Layers in } \\
\text { the Sample }\end{array}$ \\
B1 & 3.140 & 1.487 & 196 & 0.52643 & 0.86309 & 0.86309 \\
B2 & 2.974 & 1.408 & 196 & 0.52656 & 0.86341 & 1.7265 \\
B3 & 2.816 & 1.295 & 196 & 0.54013 & 0.89698 & 2.62348 \\
B4 & 2.590 & 1.127 & 196 & 0.56486 & 0.96082 & 3.5843 \\
\hline
\end{tabular}




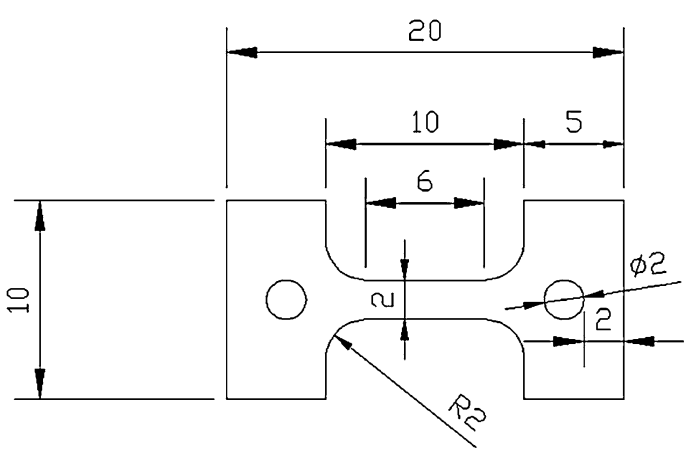

Fig. 1-The specimen drawing for tensile tests.

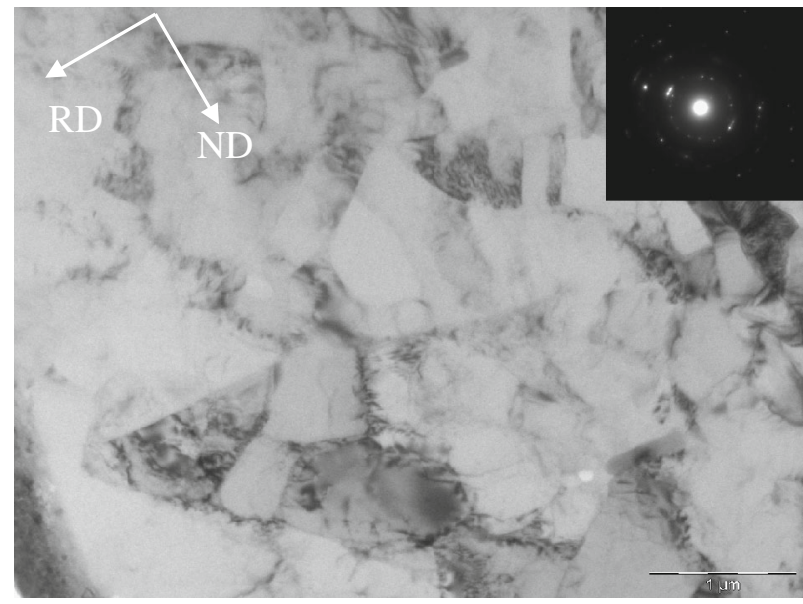

Fig. 2-Microstructure of the hot-rolled AA5050 Al alloy used as the starting material. Inset is the corresponding selected area diffraction patterns. RD and ND stand for rolling direction and normal direction, respectively.

perpendicular to the rolling direction, with spacing between 120 and $180 \mathrm{~nm}$. A group of continuous dislocations cutting through the grain was marked by the black arrow in Figure 5(b)), which might be the early stage of sub-grain boundary formation. The triple junction marked by the white arrow in Figure 5(b)) is enlarged and shown in Figure 5(c)). The misorientation can be reflected by the contrast where a high contrast indicates a high misorientation. It can be seen that the high-angle grain boundary was strongly deformed and contained a high density of dislocations. The dislocation morphology was very similar to that marked by the black arrow in Figure 5(b)), but much denser. This indicates that in the grain refining mechanism, the dislocations continuously cut through the grain and the cutting path gradually becomes the low-angle grain boundary; with further deformation, the dislocations on the path increased severely and subsequently the misorientation between the new grains at each side of the new grain boundary gradually increased to form a high-angle grain boundary. Moreover, the dispersion of fine particles of $\mathrm{Al}_{2} \mathrm{O}_{3}, \sim 10 \mathrm{~nm}$ in size, can also be seen near the grain boundary in the right grain. The best imaging conditions
Table III. Structural parameters in the starting material and the ARB-deformed samples

\begin{tabular}{lllc}
\hline Samples & $d_{l}(\mu \mathrm{m})$ & $d_{n}(\mu \mathrm{m})$ & Aspect Ratio \\
\hline Starting & 1.35 & 1.33 & 1.01504 \\
B2 Center & 0.87 & 0.38 & 2.28947 \\
B2 Edge & 0.52 & 0.33 & 1.57576 \\
B4 Center & $0.43-2.2$ & $0.16-0.22$ & 3.07564 \\
B4 Edge & $0.41-0.65$ & $0.21-0.32$ & 1.78571 \\
\hline
\end{tabular}

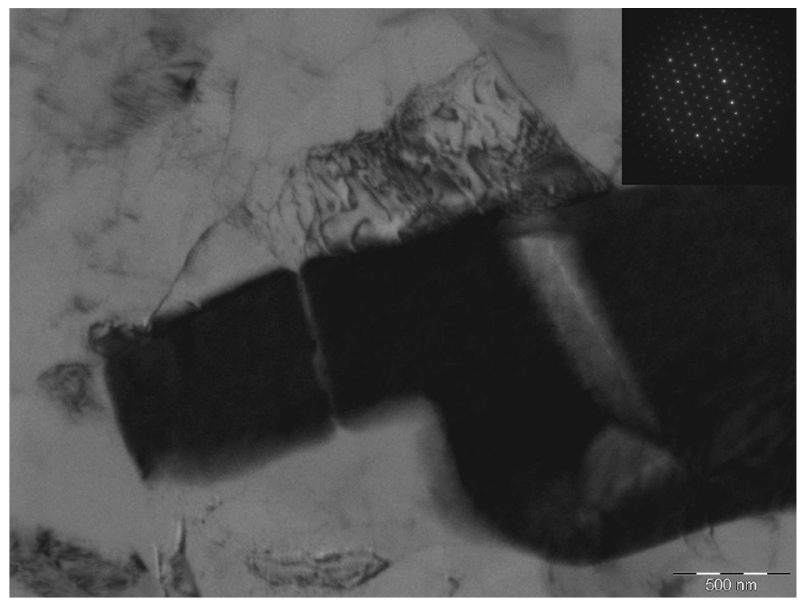

Fig. 3- $\mathrm{The} \mathrm{Al}_{3} \mathrm{Mg}_{2}$ precipitation in the hot-rolled $\mathrm{AA} 5050 \mathrm{Al}$ alloy. Inset shows the corresponding $\langle 110\rangle$ zone axis diffraction patterns.

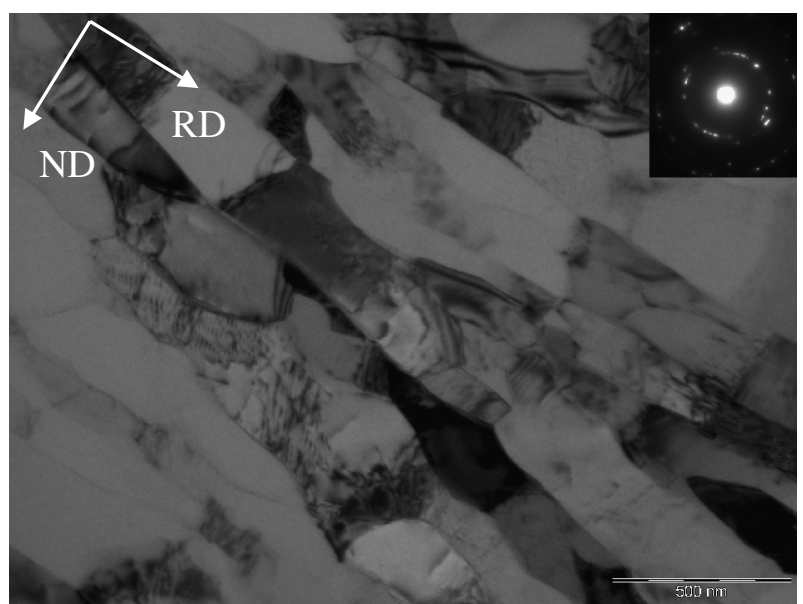

Fig. 4-Microstructure in the center of the sample after two cycles of ARB processing. Inset shows the corresponding selected area diffraction patterns.

for revealing the particles were proposed in a bright field by reducing the contrast of $\mathrm{Al}$ to a minimum and tilting the specimen to remove the contrasting dislocation and bend. ${ }^{[31]}$ These $\mathrm{Al}_{2} \mathrm{O}_{3}$ particles might pin the grain boundaries or affect the grain refining process, thereby influencing the subsequent mechanical properties.

At the final stage (4th cycle), a common lamellar deformation structure was formed in the center of the 



Fig. 5-Microstructure near the surface of the sample after two cycles of ARB processing: $(a)$ overall, $(b)$ detailed, and $(c)$ magnification of the area marked by white arrow in $b$ ). The black arrow indicates the continuous dislocation cutting.

deformed sample (Figure 6(a)). The grain boundary spacing in the ND was around $200 \mathrm{~nm}$, while the spacing in the RD varied dramatically from $500 \mathrm{~nm}$ to $2 \mu \mathrm{m}$. The average spacing of the grain boundaries in the RD is $620 \mathrm{~nm}$. The extended dislocation boundaries with a strong alignment parallel to the rolling direction were present and the in-grain dislocations were also prevalent. The selected area diffraction
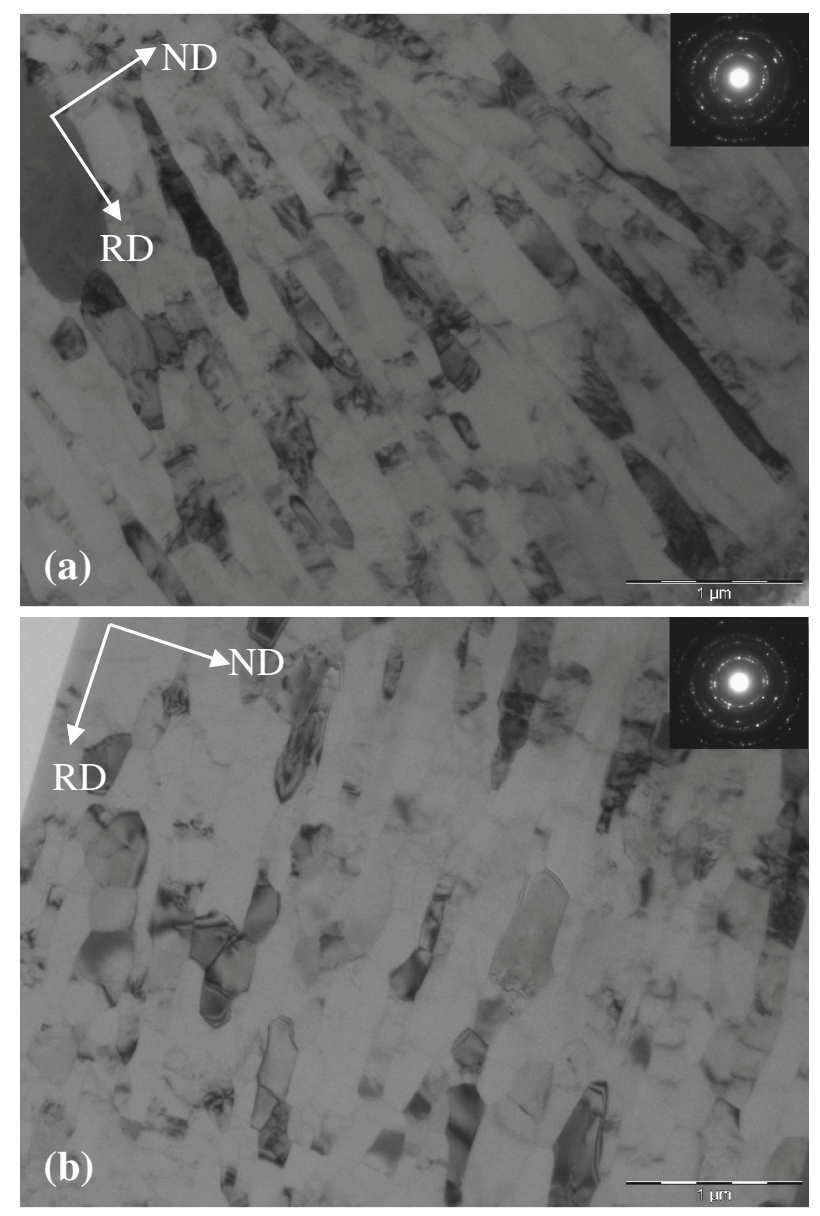

Fig. 6-Microstructure of the samples after four cycles of ARB processing: $(a)$ center and $(b)$ edge position. Insets are the corresponding selected area diffraction patterns.

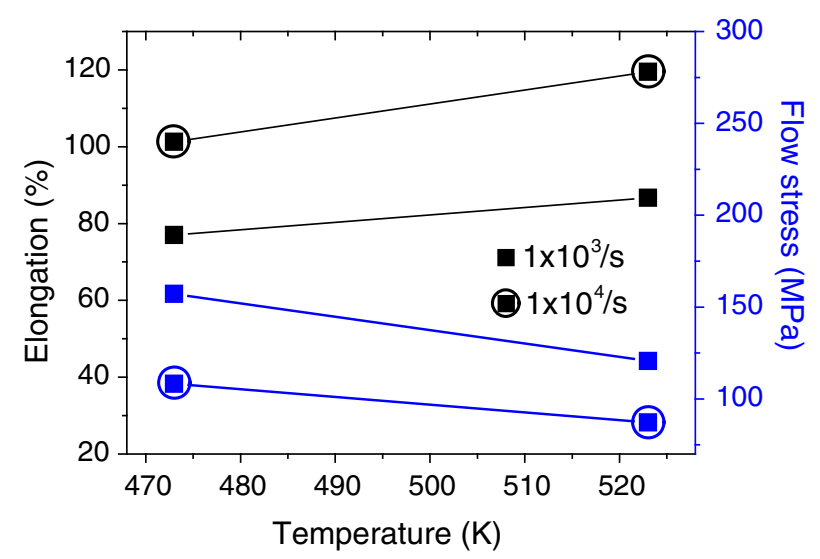

Fig. 7 - Tensile test results at $473 \mathrm{~K}$ and $523 \mathrm{~K}\left(200{ }^{\circ} \mathrm{C}\right.$ and $\left.250{ }^{\circ} \mathrm{C}\right)$ with strain rates of $1 \times 10^{3} \mathrm{~s}^{-1}$ and $1 \times 10^{4} \mathrm{~s}^{-1}$. The elongation is indicated by black patterns and the flow stress by blue patterns. The single square and circled square are for the strain rates of $1 \times 10^{3} \mathrm{~s}^{-1}$ and $1 \times 10^{4} \mathrm{~s}^{-1}$, respectively.

pattern showed a ring-like pattern, which accounted for the ultrafine-grained structure with high-angle grain boundaries generated at this stage. At the edge 
of the deformed samples (Figure 6b)), the grain refinement was predominant in both the ND and RD. Most of the grains showed a short, elongated morphology. The average grain boundary spacing was around $200 \mathrm{~nm}$ in the ND, which was similar to that in the center of the sample, and between 300 and $500 \mathrm{~nm}$ in the RD. The ring-like feature of the corresponding SAD patterns was more evident than that in the center of the sample.

Figure 7 shows the results of the tensile test at $473 \mathrm{~K}$ and $523 \mathrm{~K}\left(200{ }^{\circ} \mathrm{C}\right.$ and $\left.250{ }^{\circ} \mathrm{C}\right)$ with strain rates of $1 \times 10^{3} \mathrm{~s}^{-1}$ and $1 \times 10^{4} \mathrm{~s}^{-1}$. It can be seen that the ARB-processed AA5050 presented a larger elongation, especially with the lower strain rate (over $100 \mathrm{pct}$ ). This large elongation was mainly attributed to the ultrafinegrained microstructure. It should be noted that the strain rate affected the plasticity much more than the temperature. This implies that the contribution of the grain boundary sliding toward plastic deformation obviously increased at the lower strain rate because grain boundary sliding and accommodation depend more on the strain rate than the dislocation movement. Although the superplasticity behavior was not as obvious as the material produced by ECAP, ${ }^{[2-12]}$ it is still better than that of the normal cold-rolled materials under the same conditions.

ARB texture is generally characterized by strong rolling-type components close to the center of the sheets and shear-type components near the surface and highangle grain boundaries parallel to the rolling direction. ${ }^{[33-35]}$ TEM observations in the present study confirmed the above conclusion. The relatively low superplasticity of the ARB-processed material compared to other SPD materials is because the rolling texture cannot be eliminated and most of the high-angle grain boundaries are parallel to the rolling direction. It is expected that introducing more shear deformation by process design could reduce the rolling texture and increase the high-angle grain boundaries parallel to the $\mathrm{ND}$, which would further increase the superplasticity of the ARB-processed materials.

\section{CONCLUSIONS}

In the present study, ultrafine-grained AA5050 sheets were fabricated by the ARB process. It has been found that at the early stage of ARB, the grain size was reduced in the $\mathrm{ND}$ and became elongated along the $\mathrm{RD}$. The thin elongated grains were cut out by dense dislocations, which then tangled and condensed, resulting in the formation of dislocation cells. As the deformation proceeded, the dislocation cells evolved to sub-grain boundaries and then grain boundaries. The ultrafine-grained microstructure was obtained via four ARB cycles. The tensile tests at $473 \mathrm{~K}$ and $523 \mathrm{~K}$ $\left(200{ }^{\circ} \mathrm{C}\right.$ and $250{ }^{\circ} \mathrm{C}$ ) showed large elongations for strain rates of $1 \times 10^{3} \mathrm{~s}^{-1}$ and $1 \times 10^{4} \mathrm{~s}^{-1}$.

\section{REFERENCES}

1. M. James, ed., Interfaces in Materials, John Wiley \& Sons, Inc., New York (1997).

2. Y. Iwahashi, Z. Horita, M. Nemoto, and T.G. Langdon: Acta Mater., 1997, vol. 45, p. 4733.

3. F.J. Humphreys, P.B. Prangnell, J.R. Bowen, A. Gholinia, and C. Harris: Philos. Trans. R Soc. Lond. A, 1999, vol. 357, p. 1663.

4. P.B. Berbon, M. Furukawa, Z. Horita, M. Nemoto, and T.G. Langdon: Metall. Mater. Trans. A, 1999, vol. 30A, p. 1989.

5. C. Pithan, T. Hashimoto, M. Kawazoe, J. Nagahora, and K. Higashi: Mater. Sci. Eng. A, 2000, vol. 280, p. 62.

6. A. Yamashita, D. Yamaguchi, Z. Horita, and T.G. Langdon: Mater. Sci. Eng. A, 2000, vol. 287, p. 100.

7. R.Z. Valiev, R.K. Islamgaliev, and I.V. Alexandrov: Prog. Mater Sci., 2000, vol. 45, p. 103.

8. Y.C. Chen, Y.Y. Huang, C.P. Chang, and P.W. Kao: Acta Mater., 2003, vol. 51, p. 2005.

9. R.Z. Valiev and T.G. Langdon: Prog. Mater Sci., 2006, vol. 51, p. 881 .

10. O. Sitdikov, T. Sakai, E. Avtokratova, R. Kaibyshev, K. Tsuzaki, and Y. Watanabe: Acta Mater., 2008, vol. 56, p. 821.

11. I. Mazurina, T. Sakai, H. Miura, O. Sitdikov, and R. Kaibyshev: Mater. Sci. Eng. A, 2008, vol. 486, p. 662.

12. X. Molodova, G. Gottstein, M. Winning, and R.J. Hellmig: Mater. Sci. Eng. A, 2007, vols. 460-461, p. 204.

13. N. Tsuji, K. Shiotsuki, and Y. Saito: Mater. Trans., JIM, 1999, vol. 40, p. 765.

14. Y. Saito, H. Utsunomiya, N. Tsuji, and T. Sakai: Acta Mater., 1999, vol. 47, p. 579.

15. N. Tsuji, Y. Ito, Y. Saito, and Y. Minamino: Scripta Mater., 2002, vol. 47 , p. 893.

16. O. Sitdikov, T. Sakai, A. Goloborodko, H. Miura, and R. Kaibyshev: Mater. Trans., 2004, vol. 45, p. 2232.

17. O. Sitdikov, T. Sakai, A. Goloborodko, H. Miura, and R. Kaibyshev: Phil. Mag., 2005, vol. 85, p. 1159.

18. S. Ringeval, D. Piot, C. Desrayaud, and J.H. Driver: Acta Mater., 2006, vol. 54, p. 3095.

19. A. Belyakov, T. Sakai, H. Miura, and K. Tsuzaki: Phil. Mag., 2001, vol. A81, p. 2629.

20. R.M. Imayev, G.A. Salishchev, O.N. Senkov, V.M. Imayev, M.R. Shagiev, and N.K. Gabdullin: Mater. Sci. Eng., A, 2001, vol. 300, p. 263.

21. J. Xing, H. Soda, X. Yang, H. Miura, and T. Sakai: Mater. Trans., 2005, vol. 46, p. 1646.

22. C. Kobayashi, T. Sakai, A. Belyakov, and H. Miura: Phil. Mag. Lett., 2007, vol. 87, p. 751.

23. T. Sakai, A. Belyakov, and H. Miura: Metall. Mater. Trans. A, 2008, vol. 39A, p. 2206.

24. K. Wang, N.R. Tao, G. Liu, J. Lu, and K. Lu: Acta Mater., 2006, vol. 54 , p. 5281 .

25. K. Lu and J. Lu: Mater. Sci. Eng. A, 2004, vol. 38, p. 375.

26. N.R. Tao, Z.B. Wang, W.P. Tong, M.L. Sui, J. Lu, and K. Lu: Acta Mater., 2002, vol. 50, p. 4603.

27. C. Lu, K. Tieu, and D. Wexler: J Mater. Proc. Tech., 2009, vol. 209 , p. 4830.

28. H.W. Kim, S.B. Kang, N. Tsuji, and Y. Minamino: Acta Mater., 2005, vol. 53, p. 1737.

29. N. Kamikawa, N. Tsuji, X. Huang, and N. Hansen: Acta Mater., 2006, vol. 54, p. 3055.

30. M. Eizadjou, H.D. Manesh, and K. Janghorban: J. Alloy. Compd., 2009, vol. 474, p. 406.

31. C.Y. Barlow, P. Nielsen, and N. Hansen: Acta Mater., 2004, vol. 52 , p. 3967.

32. Q. Liu, X. Huang, D.J. Lloyd, and N. Hansen: Acta Mater., 2002, vol. 50, p. 3789 .

33. A. Kolahi, A. Akbarzadeh, and M.R. Barnett: J Mater. Proc. Tech., 2009, vol. 209, p. 1436.

34. N. Tsuji, R. Ueji, and Y. Minamino: Scripta Mater., 2002, vol. 47, p. 69.

35. N. Kamikawa, T. Sakai, and N. Tsuji: Acta Mater., 2007, vol. 55, p. 5873. 